\title{
Mirjam Vossen* and Lau Schulpen* Media frames and public perceptions of global poverty in the UK: Is there a link?
}

https://doi.org/10.1515/commun-2018-2006

\begin{abstract}
This study investigates the relationship between media frames and public perceptions of global poverty. Building on a frame analysis, the paper reconstructs prevailing poverty narratives in British news articles and non-governmental organizations' (NGO's) advertisements between 2011 and 2013. Following this, these narratives are compared with the narratives that emerge from public opinion studies. The findings suggest that there is a strong connection between media frames and public knowledge and perceptions of global poverty. Both the media and the public define poverty in developing countries' terms of destitute victims, lack of development and bad governance. Both suggest that the causes of poverty are internal to developing countries and imply that there has been little progress in reducing global poverty.
\end{abstract}

Keywords: news framing, framing effects, poverty, public opinion

\section{Introduction}

The majority of Europeans appear to have limited knowledge and understanding of the levels of poverty in developing countries. In 2013, a representative group of British respondents were asked whether they thought that the proportion of the world's poorest had increased, decreased or remained more or less the same over the last 30 years. The correct answer, that extreme poverty had been reduced, was given by only $10 \%$ of the participants while $58 \%$ percent of the respondents were convinced that the poverty problem had grown worse (Rosling, 2013). Similar surveys in other European countries point in the same direction: People tend to misjudge the basic facts regarding poverty in developing countries. They not only misunderstand the trends in declining global poverty, but also strongly

*Corresponding author: Mirjam Vossen, Centre for International Development Issues, Radboud University, Nijmegen, The Netherlands; Institute for Media Studies, University of Leuven, Leuven, Belgium, E-Mail: mirjamvossen@gmail.com

Lau Schulpen, Centre for International Development Issues, Radboud University, Nijmegen, The Netherlands, E-Mail: I.schulpen@maw.ru.nl 
underestimate the progress that has been made in health, education and fertility reduction (Danida, 2014; Gapminder, 2014; Motivaction, 2016).

This paper argues that the media play an important role in shaping public perceptions of poverty in developing countries. For most people, issues concerning poverty are at a considerable distance from their own daily lives and they primarily gather information about this topic from television, newspapers and the internet (European Commission, 2015; Henson, Lindstrom, and Haddad, 2010). This raises two questions. Firstly, how is global poverty represented by the media? And secondly, how do these representations relate to public attitudes towards the issue? As a result, the aim of this study is to examine the links between media coverage and public perceptions of poverty in developing countries.

A number of studies have investigated the representation of global poverty in the media (e.g., Bond, 2014; Cohen, 2001; Dogra, 2012; Lugo-Ocando, 2015; Van Heerde and Hudson, 2009). Some studies have focused explicitly on the coverage in the news media, others have explored the portrayal of global poverty by international development NGOs. The tone in these studies has been predominantly disapproving. Lugo-Ocando (2015), for example, criticized the news media's preoccupation with conflicts, disasters and sensational events, and its failure to place the poverty issue into a political and historical perspective. He argued that the media misrepresent the structural cause of poverty, which in his view is inequality. In the same vein, Van Heerde and Hudson (2009, p. 396) argued that the news media expose their audience to a truncated treatment of the poverty issue with little attention to its causes and consequences.

NGOs, in turn, have been specifically criticized for their use of images of the malnourished and suffering for fundraising purposes (Dogra, 2012; Manzo, 2008). Scholars have argued that such images perpetuate the stereotypical narrative that people in developing countries are passive and helpless victims that need to be 'saved' by donations and assistance from the developed world. Moreover, such imagery reinforces the idea that the developing world is a vast and backward region that is in a perpetual state of misery.

This leads to the second question: How do media representations relate to public attitudes? In this context, we propose that both news media and NGOs are important information dispensers and therefore both contribute to media representations of global poverty (Dogra, 2012; European Commission, 2015; Glennie, Straw, and Wild, 2012). The media's contribution to raising awareness is evident, for example, after a disaster such as the Indian Ocean tsunami in 2004, whereby media reporting generated massive public support for the victims. However, recent research also highlights the detrimental effects of existent portrayals of global poverty by the media (Bond, 2014; Darnton and Kirk, 2011; Van Heerde and Hudson, 2009). It is argued that the media's ongoing focus on hunger, 
conflicts and disasters leaves the audience with feelings of hopelessness, the conviction that little progress has been made over time, and increased skepticism towards the effectiveness of development aid. Over a period of time, this may erode the engagement of European citizens with global poverty altogether.

This paper links existing concerns about media-influence on the engagement of Europeans with global poverty. It investigates the relationship between media representations of global poverty and public beliefs and opinions. Our assumption is that people develop their beliefs about poverty over a long period of time. We assume that cultivation effects occur as cultivation theory states that media use leads us to believe that the real world is like the mediated world (Bryant and Miron, 2004; Potter, 2012, p. 53). In the context of this study, we suspect that exposure to mediated messages about developing countries, which are rarely supplemented with personal experiences, may contribute to the belief that life over there looks exactly like the images in the media.

Public opinions about global poverty are not a result of immediate media effects, but of a continuous exposure to repeated media messages over time. These long-term effects of media exposure are not directly observable and therefore difficult to measure (Potter, 2012, pp. 55-56). What is more, once effects do become observable, for example, when people express their beliefs in an opinion poll, it is difficult to attribute them to media-exposure. Other factors, such as personal characteristics and sociological factors, mediate the creation of perceptions (Valkenburg, Peter, and Walther, 2015).

Rather than providing evidence of the media effects on public beliefs, this paper aims to map out the relationship between the two. While a large body of literature suggests that media has an impact on public beliefs about global poverty, little is known about the connections between them. Oneexception is an investigation by Bond (2014) of 2000 articles in the British press between July 2011 and June 2013. In addition, 26 people were closely monitored over the course of six weeks and asked about their media experiences with and thoughts about global poverty. The findings suggest that there is a strong link between media coverage and audience perceptions. For instance, the media gave particular prominence to government corruption in relation to poverty in developing countries. This was reflected in the responses of the audience, who identified corruption as a major cause and consequence of poverty.

This paper expands on this existing study by examining how the issue of global poverty is presented in the media and combines it with data from public opinion studies. It asserts that both news media and NGOs can shape people's perceptions and aims to investigate the similarities between the two.

First, we conduct an analysis of poverty frames in recent news articles and NGO-advertisements. Secondly, we review existing public opinion studies to 
explore the presence of these media frames in public attitudes on the topic (see also Gamson and Modigliani, 1989; Shah, Watts, Domke, and Fan, 2002). Finally, we discuss the implications for journalists and NGOs.

This study is interested in observing the more or less solid beliefs of the general public. We have chosen therefore a period of three years to ensure that observed opinions are not heavily influenced by one-off events that attracted a lot of media-attention, such as a famine or disaster, which may cause a short-term fluctuation change effect (Potter, 2012, p. 55). The United Kingdom was chosen as a case study because the public attitudes towards global poverty and development are relatively widely studied in the UK compared to other European countries.

Our study presents aggregate results of the media coverage and public opinions regarding global poverty, hence, it does not account for differences in framing between newspapers and individual differences in perception, such as differences between various age groups. Moreover, our study of media content is limited to newspaper articles, while acknowledging that people also glean their knowledge about developing countries from other sources, such as TV and social media.

\section{Representing global poverty}

\subsection{Framing}

We use a frame analysis to study the media content and public beliefs regarding global poverty. Framing, in a broad sense, suggests how an audience should think about a topic. Frames attribute meaning to an issue. They highlight certain aspects and intimate how the issue should be interpreted (Scheufele and Tewksbury, 2007). Building frames involves the choice of topics, arguments, causal reasoning, catchwords, visuals and exemplars that communicate to the audience how the issue should be understood. For example, Bullock, Fraser Wyche, and Williams (2001) investigated how the media framed local poverty in the US. They found that the media often connected poverty to the personality traits of the poor by emphasizing their laziness and irresponsibility, and using negative catchphrases such as "welfare queens" to typify single black mothers on social assistance.

To operationalize frames we use a conceptualization by Entman (1993), who defined the functions of framing in a communicating text. According to Entman, the function of a frame is to "promote a particular problem definition, causal 
interpretation, moral evaluation, and/or treatment recommendation for the item described" (p. 52). In other words, frames on the issue of poverty tell us what is at stake, what caused poverty, which moral values are involved and how and by whom poverty should be solved. In addition, we conceptualize frames not as purely individual constructs, but as a part of a shared culture. Frames belong to a set of shared stories, world-views and beliefs with which a large group of people are familiar. Hence, both journalists and their audience are accustomed to the same set of frames. Journalists and other communicators use them to construct stories while the audience uses them to interpret a message.

\subsection{Global poverty frames}

We used a set of six predetermined frames to assess the framing of global poverty (Vossen and Van Gorp, 2016). A strict procedure was followed to inductively detect these frames (for an overview of the applied methodology, see Van Gorp, 2007, 2010). The first step was to gather a selection of documents that contained a wide variation of viewpoints about global poverty. These texts included, for example, books on development cooperation, party programs, and websites of development organizations. In this material, "framing elements" were detected and brought together in a matrix. Framing elements consist of words and sentences that tell us about the essence of poverty, its causes and consequences, solutions and moral values (Entman, 1993). Related elements were grouped until the matrix showed a limited number of distinctive frames. Each frame bore a unique description of the essence of poverty, its causes and consequences, the moral values involved, and the potential solutions. Table 1 gives a description of the frames.

Tab. 1: Global poverty frames.

\begin{tabular}{ll}
\hline Frame & Description \\
\hline Victim & The poor are innocent victims of tragic circumstances. They suffer from \\
& hunger, diseases and conflicts. The frame makes a strong moral appeal \\
& to the rich to help the needy. \\
Progress & Poverty is a lack of development. Poor people and countries need to \\
& catch up with the rich world. Solutions lie in economic development, \\
and advancements in health care, education, food production and & infrastructure. \\
Social justice & $\begin{array}{l}\text { Poverty is injustice and inequality. Societies are organized in an unfair } \\
\text { way, which denies the poor freedom and chances. Solutions lie in a fair } \\
\text { distribution of wealth and equal access to opportunities. }\end{array}$
\end{tabular}




\begin{tabular}{|c|c|}
\hline Frame & Description \\
\hline Bad governance & $\begin{array}{l}\text { Poverty is linked to failing governance in poor countries. Leaders and } \\
\text { elites behave irresponsibly and contribute to corruption, fraud and con- } \\
\text { flicts. Solving poverty requires improving local institutions. }\end{array}$ \\
\hline Blame us & $\begin{array}{l}\text { The rich world harms the poor world: Through colonization and slavery } \\
\text { in the past, nowadays through exploitation and unfair trade systems. } \\
\text { The solution to global poverty lies in the West. }\end{array}$ \\
\hline Global village & $\begin{array}{l}\text { In a globalizing world all people and countries are interconnected. } \\
\text { Rich and poor countries alike have a mutual responsibility to tackle } \\
\text { cross-border issues, which disproportionally affect the poorest. }\end{array}$ \\
\hline
\end{tabular}

Note: Adapted from Vossen and Van Gorp, 2016.

An additional point is worth noting at this stage. Our study links up with criticisms of stories that merely problematize the situation in developing countries. For this reason, we want to assess the extent to which such a "problematizing portrayal" is reflected in news articles and NGO-advertisements. However, a frame in itself does not always disclose whether a message is positively or negatively charged. For instance, the progress frame can be used to talk about a lack of schools and teachers in developing countries (problematizing). Conversely, the frame can also be used to highlight the advancements in developing countries, such as increased school enrolment (de-problematizing). We will refer to this 'problematizing' or 'de-problematizing' emphasis as the 'tone of voice' in the message.

Our objective here is not simply to count the frequency of the frames or framing elements and the frequency of problematizing messages. Rather, our aim is to look for patterns in the media coverage with regard to the framing, the tone of voice, and the attention given to causes, remedies and responsibility for the solution. In this respect, infrequently used perspectives are just as important as frequently used perspectives (Entman, 1993, p. 54). We will refer to these patterns as the overarching narrative. In conclusion, our objective is to reconstruct the overarching global poverty narrative in the media and in public opinion which highlights prevailing as well as underexposed perspectives on poverty. From this we derive the following research questions:

$R Q$ 1: What is the overarching narrative regarding global poverty in news articles and NGO-advertisements?

$R Q$ 2: What is the overarching narrative regarding global poverty in public opinion and how does it relate to the narrative of the media? 


\section{Method}

\subsection{Data collection}

We used three datasets for our analysis all originating from the UK: newspaper articles, NGO-advertisements and public-opinion studies. We selected articles from a mix of broadsheet, mid-market and tabloid papers, with a political orientation ranging from center right to center left (The Guardian, The Daily Telegraph, The Times, The Sun, and The Daily Mirror). The search was undertaken with LexisNexis, and the articles had been published from January 2011 to December 2013. Our search terms were derived from the frame descriptions and included words such as "poverty", "development", "aid", "hunger", and "dictator". The search was confined to stories about countries that are on the OECD-DAC list of developing countries (OECD, 2013). Our search generated stories that problematized poverty in developing countries, but also stories about advancements and the decline of poverty in developing countries. The initial search returned 5,609 articles. After the removal of irrelevant stories (for example, about football in Africa), 1,984 articles remained. From these we randomly selected every fifth article. We evaluated the articles again for their relevance, and finally 357 articles remained for analysis.

Our second dataset consisted of 73 NGO-advertisements from 24 British development organizations, which had been published or broadcast between January 2011 and December 2013. Our purpose was to examine the messages about poverty with which the audience had come into contact coincidentally, that is, without making any special effort. Our search was therefore limited to messages in the mass media, such as television and radio advertisements and advertisements in print media. The data collection started with large NGOs that regularly conduct media campaigns. The membership list of Bond, the NGO-umbrella organization, served as a starting point. Part of the material was given or sent to the researchers by NGOs, part was retrieved through the internet, for example, through the organization's website or YouTube channel. The sample is not representative; there is no overview of all published NGO-advertisements, so the drawing of a reliable sample is impossible. However, given the size of the collection and the variety of organizations in our sample, we expect that our collection is a reasonable reflection of the advertisements that were distributed in this period.

Our third and final dataset consisted of studies into public attitudes, opinions and the level of knowledge of the British public regarding global poverty and development issues. Our goal was to bring together all the studies on the data collected between 2011 and 2013. In addition, two representative surveys from 2010 
were included. Our dataset contained nine studies, conducted or commissioned by Bond, the European Commission, Gapminder, TNS, ODI and YouGov (see Table 2). We utilized both quantitative and qualitative studies. This was a deliberate choice. It has been argued that survey tools are not well suited to examining attitudes to complex issues, of which global poverty is an example (Carabain, 2007; Glennie, Straw, and Wild, 2012; Hudson and van Heerde-Hudson, 2012). Surveys, for instance, often inquire about respondents' levels of agreement with a certain statement, thereby failing to expose ambivalence towards an issue. Moreover, specific wording of questions and statements may influence people's answers. Such limitations can be partly overcome by qualitative research, for example, interviews or focus group discussions, which offer more scope for nuance and depth. We therefore expect the involvement of both types of research to increase the validity of our analysis. However, this comes at the expense of providing exact percentages: We will not be able to state, on the basis of qualitative studies, that a certain percentage of the people endorse a certain vision. Hence, our investigation of public opinion studies will merely allow us to detect recurring themes and patterns.

Table 2: Overview of public opinion studies into British people's attitudes towards international development between 2010 and 2014.

\begin{tabular}{|c|c|c|c|c|}
\hline Year & Publisher & Title & Type & Topics \\
\hline 2010 & TNS UK & $\begin{array}{l}\text { Public attitudes towards } \\
\text { development }\end{array}$ & survey & $\begin{array}{l}\text { corruption perceptions; } \\
\text { causes of poverty; } \\
\text { actions of government }\end{array}$ \\
\hline 2010 & $\begin{array}{l}\text { European } \\
\text { Commis- } \\
\text { sion }\end{array}$ & $\begin{array}{l}\text { Europeans, development } \\
\text { aid and the Millennium } \\
\text { Development Goals }\end{array}$ & survey & $\begin{array}{l}\text { challenges of develop- } \\
\text { ing countries; desired } \\
\text { policies }\end{array}$ \\
\hline 2011 & $\begin{array}{l}\text { European } \\
\text { Commis- } \\
\text { sion }\end{array}$ & $\begin{array}{l}\text { Making a difference in } \\
\text { the world: Europeans and } \\
\text { the future of develop- } \\
\text { ment aid }\end{array}$ & survey & $\begin{array}{l}\text { consumer behavior; } \\
\text { desired policies }\end{array}$ \\
\hline 2012 & IPPR/ODI & $\begin{array}{l}\text { Understanding public } \\
\text { attitudes to aid and } \\
\text { development }\end{array}$ & $\begin{array}{l}\text { focus } \\
\text { groups* }\end{array}$ & $\begin{array}{l}\text { perceptions of poverty } \\
\text { and aid; responsibility } \\
\text { for solutions }\end{array}$ \\
\hline 2012 & YouGov & $\begin{array}{l}\text { What causes extreme } \\
\text { poverty in developing } \\
\text { countries }\end{array}$ & $\begin{array}{l}\text { online } \\
\text { query }\end{array}$ & causes of poverty \\
\hline 2013 & Gapminder & $\begin{array}{l}\text { Highlights from the igno- } \\
\text { rance survey }\end{array}$ & survey & $\begin{array}{l}\text { knowledge of poverty-re- } \\
\text { lated issues }\end{array}$ \\
\hline 2013 & $\begin{array}{l}\text { European } \\
\text { Commis- } \\
\text { sion }\end{array}$ & $\begin{array}{l}\text { EU Development Aid and } \\
\text { the Millennium Develop- } \\
\text { ment Goals }\end{array}$ & survey & $\begin{array}{l}\text { knowledge of number of } \\
\text { poor; consumer behav- } \\
\text { ior; post } 2015 \text { develop- } \\
\text { ment policies }\end{array}$ \\
\hline
\end{tabular}




\begin{tabular}{lllll}
\hline Year & Publisher & Title & Type & Topics \\
\hline 2014 & BOND & Change the record & $\begin{array}{l}\text { tracking } \\
\text { study } \\
\text { and focus } \\
\text { groups* } \\
\text { survey }\end{array}$ & $\begin{array}{l}\text { causes of poverty; solu- } \\
\text { tions to poverty; role of } \\
\text { governments; corruption } \\
\text { perceptions } \\
\text { corruption perceptions; } \\
\text { ways of delivering aid; } \\
\text { actions of government }\end{array}$ \\
\hline
\end{tabular}

Note: All surveys in this overview were representative surveys.

* Participants of these focus groups reflected the middle ground; strong opponents and enthusiasts of development cooperation were excluded.

\subsection{Coding the news articles and NGO-advertisements}

The coding of the newspaper articles and NGO-advertisements was carried out by nine coders, who had undergone intensive preparation. ${ }^{1}$ They were familiarized with the frames and asked to identify them in the material. As a guideline, they used a list with interpretative questions with which to detect the presence of a frame. ${ }^{2}$ For example, the question, "Does the message give examples of progress or decline in developing countries?” indicated the presence of the progress frame. The question, "Does the message suggest that the problems are caused by bad leadership or bad governance?” was an indicator of the bad governance frame.

After carefully reading, viewing, or listening to each text, coders holistically coded whether one of the frames was present (Matthes and Kohring, 2008). They could record up to two frames. When they discovered more frames, they noted the most important ones. These were, for instance, the frames that appeared in the headline and lead, or the frames that were used most often in the subparagraphs. When none of the frames were present, they coded "no frame". This was the case, for example, in short and completely factual news articles. Next, coders answered a question about the tone of voice of the message. More specifically, they indicated whether the article or advertisement merely problematized

1 The study was part of a larger analysis of 876 news articles and 284 NGO-advertisements from the Netherlands, Flanders and the United Kingdom. The coding of news articles and NGO-advertisements was performed between November 2013 and March 2014. Newspaper articles were coded by one researcher and six (former) students of communication at the Radboud University and the University of Wageningen. NGO-advertisements were coded by one researcher, an intern of Partos and two students at the Institute of Media Studies of the Catholic University in Leuven. Public opinion studies were coded in May 2016 by the two researchers.

2 The coding scheme is available from the corresponding author on request. 
the situation, or whether it (also) paid attention to positive developments and advancements. For newspaper articles, the answers were coded on a five-point Likert scale, ranging from "strong emphasis on problems" to "strong emphasis on achievements". When both sides were equally highlighted, the message was coded as "balanced". Articles with an emphasis on problems, for example, reported troubled elections, refugees on the run or the exploitation of laborers. Articles with an emphasis on positive developments, for example, paid attention to economic growth in developing countries or gave examples of successful development interventions.

For NGO-advertisements, the question was phrased slightly differently. Coders answered whether the advertisement mentioned achievements or displayed tangible results, for instance, by showing how previous interventions had improved people's lives. The answers were coded on a three-point Likert scale ranging from "yes" to "a little" to "no".

Some of the advertisements (10\%) and news articles (13\%) were double coded. ${ }^{3}$ For the nominal variables, Krippendorff's Alpha was used as a measure of reliability. This measure corrects the percentage of agreement between the coders for chance agreement (see Krippendorff, 1982). Spearman's rho was used as the measure for the Likert scale whereby an Alpha or rho of 0.60 was considered acceptable. The measures were as follows. News articles: victim frame: 0.68; progress frame: 0.77; social justice frame: 0.67; bad governance frame: 0.64; blame us/global village frame: 0.69; emphasis on problems/advancements: 0.67. NGO-advertisements: poverty frames combined 0.78; displaying results: 0.71 .

\subsection{Coding the public opinion studies}

Coding the public opinion studies was less straightforward than coding the media content. First, the studies at hand were not mutually comparable. This applied to both qualitative and quantitative investigations. Secondly, the primary objective of most studies was to measure people's attitudes towards (government) development aid. Questions about their attitudes towards the poverty issue in general played a secondary role. Consequently, many of the questions were not relevant for our study.

Therefore, the analysis took place in two phases. During the first phase we separated out the relevant questions and answers from each study (see also

3 Articles for double coding were selected from the larger database of 876 news articles and 284 advertisements; see also Note 1. 
Gamson and Modigliani, 1989). The "framing functions" of Entman (1993) served as a guideline: We selected questions and answers that concerned people's opinions regarding the definition of the problems, causes, effects and solutions to global poverty. For example, the answers to the question, "What are, in your view, important causes of poverty?” would be selected. The answers to the question, "Should your government increase or decrease the budget for development aid?" would not be selected. In addition, we included questions that tested people's knowledge about poverty-related issues or asked about their general perception of the situation in developing countries.

In the second phase, we coded the responses of the selected questions. This was carried out by two coders. For this purpose, the same coding scheme was used as in the analysis of news articles and NGO-advertisements. The word "message" was replaced by "respondents". For example, the question, "Does the message suggest that the problems are caused by bad leadership or bad governance?" would be altered to, "Do the respondents suggest that the problems are caused by bad leadership or bad governance?"

During the coding it was observed that many surveys used prompt lists to expose the public's opinions. These lists often omitted certain categories of answers. For instance, when asking about solutions to poverty, the lists did not include items that referred to a change of behavior in the West, hence, the lists themselves generated a certain framing of the answers. This shortcoming was overcome by also using qualitative research in which participants were asked to respond spontaneously.

Survey results were judged somewhat differently from the qualitative studies. Surveys often generated a table or graph depicting the frequency of various answers. Answers that occurred most frequently were regarded as an indicator of the presence of audience frames. For example, a TNS-survey (2010) asked respondents about the main causes of poverty. The most frequent response (56\%) was "corrupt leaders/governments", which was subsequently linked with a bad governance audience frame. When reviewing qualitative studies, the coders looked for indications such as "significant finding during the workshop", "large number of respondents", and "numerous references" in order to confirm audience frames. In this way, recurring frames and framing elements in the public's opinion were exposed, which were then compared with the frames in the news articles and NGO campaigns. 


\section{Results}

\subsection{Global poverty narratives in news articles and NGO-adver- tisements in the UK}

\subsubsection{Overall global poverty frame: Victims, (under)development and bad governance}

The UK news media considered global poverty through three predominant perspectives: the (lack of) development, innocent victims, and bad governance (see Table 3). The (lack of) development was emphasized through the progress frame, which was used in $37 \%$ of the news articles and $26 \%$ of the NGO-advertisements. News articles reported, for instance, the influence of China on Africa's economy or the advancement of green energy in developing countries. In particular, within NGO-advertisements, the progress frame was used to highlight specific aid programs, for example, used to improve education or food production. News articles and NGO-advertisements with this frame had an equivalent problematizing and de-problematizing tone of voice.

Table 3: Framing of global poverty in newspaper articles and NGO-advertisements.

\begin{tabular}{lll}
\hline Frame & Newspapers (\%) (N=357) & NGOs (\%) (N=73) \\
\hline Victim & 31 & 79 \\
Progress & 37 & 26 \\
Bad governance & 27 & 1 \\
Social justice & 13 & 10 \\
Blame us & 12 & 0 \\
Global village & 13 & 1 \\
No frame & 6 & 8 \\
\hline
\end{tabular}

Note: The figures represent the percentage of all articles/advertisements on global poverty using a particular frame. The percentages add up to more than $100 \%$ because a message may contain multiple frames.

The second predominant perspective, that of innocent victims, was by far the most important in NGO-advertisements (79\%). These messages highlighted the deplorable circumstances of people in developing countries due to hunger, disease and wars. The victim frame was not only used in emergency appeals after crisis and disasters, but also in messages that drew attention to chronic poverty conditions, such as the lack of clean water and malnutrition. In newspapers, the victim frame 
was seen in nearly one-third of the stories (31\%). The frame was mostly used in a problematizing context of disasters, wars and refugee flows, such as the crisis in the Horn of Africa in 2011 and the ongoing war in Syria.

The third important perspective in newspapers was bad governance (27\%). It linked global poverty to incompetent leadership, corruption and local conflicts. The bad governance frame was used often in articles with a political news angle, and the tone of voice was almost invariably problematizing. In contrast to the news articles, the bad governance frame was virtually absent in NGO messages. If their advertisements were linked to political conflicts, such as in Syria, they portrayed the victims rather than making inferences about failing leadership.

During the analysis, attention was also given to frames that were used less frequently and thus pointed to seldom referenced perspectives in the media. Three frames, social justice, blame us, and global village, were observed in only 12 to $13 \%$ of newspaper articles and in 0 to $10 \%$ of the NGO-advertisements (see Table 2). The social justice frame regards injustice and inequality as the root causes of poverty. Stories with this frame draw attention to the violation of rights or people living in poverty. A few NGOs used the frame, for instance, in campaigns against child marriage. This frame was also seen in some news articles regarding, for example, the exclusion of people with disabilities and the rift between the middle class and the chronically poor in developing countries.

The other sparingly used frames - blame us and global village - have in common an emphasis upon the accountability of the West for the poverty in developing countries. Blame us asserts that the rich world harms the poor world. It was seen, for example, in news stories about the collapse of a factory in Bangladesh that produced clothes for the Western market. In the same vein, global village turns attention to the West, by pointing at the joint responsibility of rich and poor countries for the resolution of global issues. It appeared, for instance, in some news stories about the mitigation of global warming. These frames were practically absent in NGO-advertisements.

\subsubsection{Internal causes, external solutions}

Both news stories and NGO-advertisements suggested that the origins of poverty were located in developing countries. Hardly any of the NGO-advertisements made explicit references to the causes of the problem. Few explanations were given as to why there were food shortages, disease or abandoned children. Destitution in developing countries was presented as a given, for example, with phrases like "In Africa, 8 children will die this very minute" (Action Aid, 2013). 
The NGO-advertisements therefore merely highlighted the tragic consequences of this 'reality' for people living in poverty.

Newspapers wrote about the causes of poverty more often. During the analysis, it was observed that approximately two-thirds of the articles cited a cause and in most of these stories the blame was put on local governments in developing countries. Newspapers often linked the causes of poverty to mismanagement, corruption and local conflicts in developing countries.

While both newspapers and NGOs suggested that the causes of poverty were predominantly located in developing countries, they both implied that the solution should first and foremost come from the developed world. About two-thirds of the newspaper articles suggested a remedy to improve the situation, and the majority of those articles pointed at the responsibility of Western governments and institutions. They suggested that donor countries and international organizations should take action, for instance, through emergency relief to refugees, development assistance or literally paying for the consequences of climate change. Similarly, NGO-advertisements, most of whom had a fundraising purpose, suggested that the NGOs and the donating public were the agents of change. Advertisements communicated that NGOs could save lives, provide clean drinking water and cure diseases with the support of the British public. It was noted that few advertisements mentioned how the local populations were themselves taking action to improve their lives.

\subsubsection{Advancements in developing countries}

A story that received little attention was that of advancements in developing countries. The tone of voice in the media was mostly negative (Figures 1 and 2). In news articles, $64 \%$ had a negative tone of voice opposed to $19 \%$ that underscored advancements, progressions and results. In NGO-advertisements, 63\% made no reference to what had been accomplished and limited themselves to mentioning existing needs. Negativity was, self-evidently, strongest in news articles and appeals about hunger, conflicts and refugees. However, it was noted that most news articles about social issues such as health, education, agriculture and children also emphasized problems rather than advances. This finding stood out because studies show that much progress is being made in these areas. For example, over the past 25 years, child mortality in developing countries has declined by more than half and school enrolments have increased to $91 \%$ (http:// www.un.org/millenniumgoals). However, these positive trends were not reflected in the newspaper coverage. Similarly, NGO-advertisements rarely communicated any tangible results of their own projects and programs in these areas. 


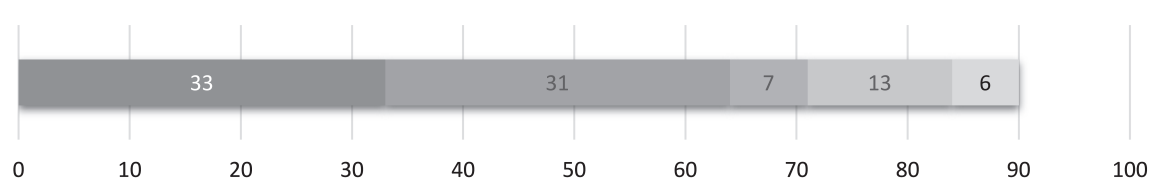

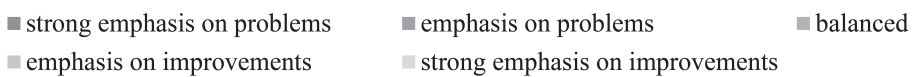

Fig. 1: Tone of voice in British newspaper articles published between 2011 and 2013 ( $N=357)$. Percentage of articles (strongly) emphasizing problems or achievements.

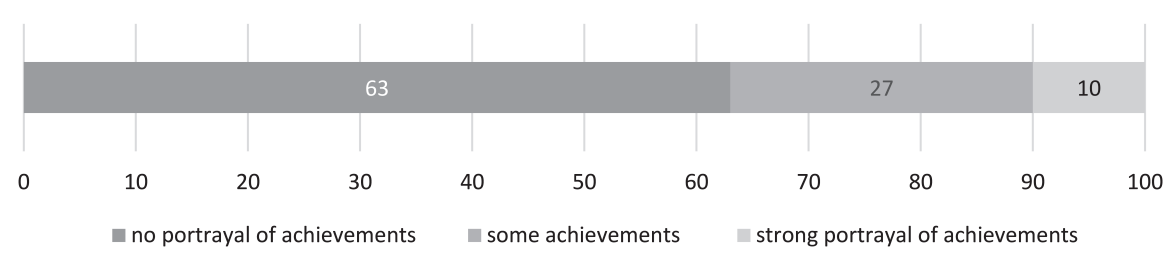

Fig. 2: Tone of voice in British NGO-advertisements between 2011 and $2013(\mathrm{~N}=73)$. Percentage of advertisements that strongly, moderately or not at all displayed achievements.

In addition, there was virtually no coverage of 'good' or 'responsible' local governance in the media. The 'bad governance' narrative was rarely countered by examples of discontinued conflicts, peace and better governance in general. Consequently, newspapers reflected the narrative that good governance in developing countries does not exist. Development organizations, as previously stated, avoided the 'governance' topic altogether.

\subsection{The public narrative regarding poverty in developing countries}

\subsubsection{Poverty is linked to destitution, corruption, and a lack of basic needs}

When asked to consider the situation in developing countries, the first things that came to people's minds were poverty, hunger, conflicts and barren, rural African landscapes. The poor were thereby regarded as passive and helpless with little agency to change their situation (Bond, 2014; Glennie et al., 2012). When asked to expand upon the causes of poverty, people primarily explained it as a result of internal, localized problems such as a lack of clean water, food, access to health 
care and education, and corruption. Bad governance was also frequently mentioned as a cause of poverty (Bond, 2014; Glennie et al., 2012; TNS, 2010). For instance, in a survey by TNS (2010), $56 \%$ of the respondents spontaneously mentioned "corrupt leaders/governments" as the main cause of poverty. Then came "lack of education", which was mentioned by $23 \%$ of the respondents.

These public perceptions corresponded to the dominant narratives in the media in which innocent victims, the lack of development, and bad governance were prominent themes. Moreover, public perception that the causes of poverty within developing countries were largely internal was also in line with the dominant narrative in the media.

\subsubsection{Poverty is also linked to our behavior}

Even though the public located the causes of poverty as mainly in developing countries, some studies found that people also considered the connections between the Western world and developing countries and their effects upon global poverty. They referred, for example, to "historical injustices as contributing to poverty and underdevelopment” (Glennie et al., 2012, p. 16). Moreover, $60 \%$ of the British public said they were willing to pay a little more for products originating from developing countries (European Commission, 2013). This indicates that there is some awareness of the interconnectedness between consumer culture in the West and poverty in developing countries. Little reference, however, was made to the current global order and the role of dominant international companies and organizations (YouGov, 2012). This perspective was also infrequently referenced in the media.

\subsection{3 "Nothing has changed"}

The British public appeared to have a strong sense that there has been no progress in reducing poverty in developing countries. This was strongly reflected in qualitative research: People were convinced that nothing had changed over the past decades and emphasized this with comments such as, "(people) keep on seeing the same adverts on the telly with no improvement” (Glennie et al., 2012, p. 14). This sense of stagnation was also reflected in survey questions about the situation in developing countries in which people were asked to make an estimate on some real world indicators of global poverty. A Eurobarometer survey found that only $8 \%$ of the British respondents correctly guessed that the number of extremely poor was between 500 million and 1 billion: $73 \%$ overestimated the 
number, while 3\% underestimated it (European Commission, 2013). Moreover, the British misjudged major trends in declining poverty, such as the proportion of people living in poverty, literacy rates and life expectancy (Rosling, 2013). For example, only $10 \%$ knew that the proportion of people living in extreme poverty has declined over the past 30 years. These misperceptions corresponded with the media narrative which paid little attention to positive developments and "slow progress" in developing countries. In short, both NGOs and newspapers reported very little on progress; the public did not think there had been any progress.

\subsubsection{Local governments should solve poverty - but they cannot be trusted}

When people were asked to spontaneously come up with solutions to global poverty, it proved difficult for them to give coherent answers. One study talked about "a scattergun list of contrasted, unconnected ideas", ranging from "cancelling debt, to women's rights, to ending conflict” (Bond, 2014, p. 17). When confronted with prompt lists, people favored tangible remedies such as investments in education, health care or development projects in general (TNS, 2010).

However, while people had disparate ideas about what needed to be done, they had a rather clear idea about who should take action. On the one hand, people felt that local governments had an important responsibility with regard to solving the poverty issue (Glennie et al., 2012). On the other hand, they thought it was a very bad idea to actually give money to these governments because they were too corrupt. For example, only $3 \%$ of the British public thought that their government giving money to the governments of poor countries was a good idea (Black, 2014). Another study concluded that the solution to poverty was to bypass local governments and give resources and finances to the people who need them (Bond, 2014, p. 21). This is in line with the strong perceptions of corruption and wastage that were reflected throughout the public opinion studies. For example, $73 \%$ of the British public believed that "a lot of overseas aid (...) ends up in the pockets of corrupt officials" (Black, 2014, p. 26) and 53\% agreed that "most financial aid to poor countries is wasted" (TNS, 2010, p. 28).

Consequently, the British public thought that Western donors and multilateral organizations should play a key role in tackling poverty in developing countries as they could be better trusted to spend the money effectively. Local citizens in developing countries were not given an important role: The public perceived them as having little knowledge or agency (Glennie et al., 2012).

In conclusion, the public distrust of local leadership in developing countries corresponded with the portrayal of local governance in the news media. Simi- 
larly, the public, newspapers and NGO-advertisements suggested that Western donors and institutions were best equipped to alleviate the suffering and boost development in developing countries.

\section{Discussion}

This research compared the narratives regarding global poverty in British news articles and NGO-advertisements with the public narrative. Our conclusion is that the public narrative largely corresponds with the media narrative. Both narratives define poverty as a localized problem, characterized by destitution, a shortage of basic needs and a lack of development. More specifically, the news media advance the narrative of bad governance in developing countries, which is reflected in strong public perceptions of corruption and little confidence in local governments in developing countries. In addition, NGOs narrate the story of destitute victims that need to be helped by 'us', which is mirrored in the public's preference for tangible solutions offered by Western donors. Both the media and the public pay relatively little attention to perspectives of justice and equality, and the liability of the West for the poverty of the developing world.

Having identified a relationship between media coverage and public perceptions, the question is the extent to which the media shape people's viewpoints. To begin with, we do not argue that the media are the only or even the strongest driving force in the formation of public perceptions. A host of factors intervene in this process such as existing knowledge, personal values, and social environment (see, for example, Valkenburg, Peter, and Walther, 2015). Moreover, people are exposed to a wider variety of media frames than are examined here, for example, through television and the internet. Finally, our findings in themselves do not prove the direction of the correlation between media narratives and public narratives. We do not know if the public constructs poverty narratives because they are in the news. It is also possible that the media reflects the existing ideas and beliefs of the public. Given that journalists themselves are part of the public and have their own beliefs on this subject, it seems likely that there is at least some interplay.

We argue, however, that the media are a powerful force in this interplay. Our first reason to assume that the media shape public perceptions is because the public say they do. In several studies, people discussed the role of the media and widely acknowledged that media coverage influenced their views on developing countries and their feelings towards extreme poverty (Bond, 2014; Glennie et al., 2012). Secondly, both news media and NGOs have specific objectives that compel 
them to present a specific version of reality in developing countries. The primary objective of NGO-advertisements is to raise funds for development interventions. This objective therefore incites them to highlight the misery, low standard of living and dependence of people in the developing world. News media, in turn, are predisposed to report about problems and to hold those in power accountable, rather than to report about, things that are improving. Consequently, their coverage is skewed towards conflicts, bad governance, disasters and misery in general.

In conclusion, we argue that the media contribute to public perceptions of bad governance, enduring misery and the persistent idea that 'we' need to help 'them'. This is problematic for two reasons. First, it reinforces stereotypical images of developing regions as dependent, backward and stagnant. Secondly, it undermines long-term engagement with global poverty and support for international development. If people come to believe that no progress is being made in developing countries, they may conclude that cooperating in development has not been very effective (Bond, 2014).

However, our study also suggests that news media and NGOs have the ability to modify public perceptions. Journalists could question their one-sided focus on bad news and find ways to pay attention to positive trends; not by treating them as single news events, for example, after the publication of a study about declining child mortality, but as a structural part of their reporting. Moreover, they could use a greater variety of frames, and highlight poverty more often from the perspective of justice, global interconnectedness and the role of the West. This too could contribute to a broader public understanding of the causes and consequences of poverty and its remedies. NGOs, in turn, could think critically about their own contribution to perceptions of helplessness and enduring misery. This study suggests that other frames, such as progress and social justice, could be less stereotyping than the victim frame. More importantly, it suggests that NGOs, as well as news media, should not only use the mass media to expose existing needs, but also to communicate achievements.

The current framing study connected media frames and public perceptions on a societal level. As such, it could serve as a model for similar investigations into the linkages between the mediated reality and people's minds. Topics could include, for example, the debate on refugees, the future of the European Union and climate change. This would not only help to better understand the media's contribution to public opinion formation, it would also enrich the field of framing research with studies beyond the level of media content analyses. 


\section{References}

Action Aid (2013). Please save a child's life today. Retrieved November 4, 2013 from https:// www.youtube.com/watch?v=TyNk49CNNfl.

Black, T. (2014). Aid Attitude Tracker - Wave 1: Summary of results. Bill \& Melinda Gates Foundation. Retrieved March 9, 2016 from my.bond.org.uk/resource/aat-quant-wave-1resultsjan-2014.

Bond (2014, November 1). Change the record. Exploring new ways to engage the UK public in tackling global poverty. Retrieved February 1, 2016 from https://www.bond.org.uk/ resources/change-record.

Bryant, J., \& Miron, D. (2004). Theory and research in mass communication. Journal of Communication, 54(4), 662-704.

Bullock, H. E., Fraser Wyche, K., \& Williams, W. R. (2001). Media images of the poor. Journal Of Social Issues, 57(2), 229-246.

Carabain, C. (2007). Taking too much for granted? A study on the measurement of social attitudes. Doctoral dissertation. Vrije Universiteit, Amsterdam.

Cohen S. (2001). States of denial: Knowing about atrocities and suffering. Cambridge: Polity Press.

Danida (2014). Danskernes holdninger og kendskab til udviklingsbistand 2014. Retrieved September 5, 2015 from http://um.dk/da/danida/det-goer-vi/u-landsoplys/danskernesholdninger-og-kendskab-til-udviklingsbistand-2013.

Darnton, A., \& Kirk, M. (2011). Finding frames: New ways to engage the UK Public in Global Poverty. London: Bond

Dogra, N. (2012). Representations of global poverty: Aid, development and international NGOs. New York: I. B. Tauris \& Co Ltd.

Entman, R. M. (1993) Framing: Toward clarification of a fractured paradigm. Journal of Communication, 43(4), 51-58.

European Commission (2010). Europeans, development aid and the Millenium Development Goals (Special Eurobarometer 352). Brussels: TNS Opinion \& Social.

European Commission (2011). Making a difference in the world: Europeans and the future of development aid (Special Eurobarometer 375). Brussels: TNS Opinion \& Social.

European Commission (2013). EU development aid and the Millennium Development Goals (Special Eurobarometer 405). Brussels: TNS Opinion \& Social.

European Commission (2015). The European Year for Development - Citizens'views on development, cooperation and aid (Special Eurobarometer 421). Brussels: TNS Opinion \& Social.

Gamson, W. A., \& Modigliani, A. (1989). Media discourse and public opinion on nuclear power: A constructionist approach. American Journal of Sociology, 95(1), 1-37.

Gapminder (2014). Ignorance Survey: Germany 2014. Retrieved April 7, 2016 from http://www. gapminder.org/GapminderMedia/wp-uploads/German-Ignorance-2014.pdf.

Glennie, A., Straw, W., \& Wild, L. (2012). Understanding public attitudes to aid and development. Institute for Public Policy Research (IPPR)/Overseas Development Institute (ODI). Retrieved August 22, 2012 from http://www.ippr.org/files/images/ media/files/publication/2012/06/public-attitudes-aid-development_June2012_9297. pdf?noredirect=1. 
Henson, S., Lindstrom, J., \& Haddad, L. (2010). Public perceptions of international development and support for aid in the UK: Results of a qualitative enquiry. Brighton: Institute of Development Studies.

Hudson, D., \& van Heerde-Hudson, J. (2012). 'A mile wide and an inch deep': Surveys of public attitudes towards development aid. International Journal of Development Education and Global Learning, 4(1), 5-23.

Krippendorff, K. (1982). Content analysis: An introduction to its methodology. Beverly Hills, CA: Sage.

Lugo-Ocando, J. (2015). Blaming the victim: How global journalism fails those in poverty. London: Pluto Press.

Manzo, K. (2008). Imaging humanitarianism: NGO identity and the iconography of childhood. Antipode, 40(4), 632-657.

Matthes, J., \& Kohring, M. (2008). The content analysis of media frames: Toward improving reliability and validity. Journal of Communication, 58(2), 258-279.

Motivaction (2016). Enquête voor The World's Best News. Retrieved August 11, 2016 from http:// www.worldsbestnews.nl/motivaction.

OECD/DAC (2013). DAC list of ODA recipients. Retrieved April 7, 2016 from http://www.oecd. org/dac/stats/documentupload/DAC\%20List\%20used\%20for\%202012\%20and\%20 2013\%20flows.pdf.

Potter, W. J. (2012). Media effects. Thousand Oaks, CA: SAGE Publications.

Rosling, H. (2013). Highlights from Ignorance survey in the UK. Retrieved April 7, 2016 from Gapminder http://www.gapminder.org/news/highlights-from-ignorance-survey-in-the-uk.

Scheufele, D. A., \& Tewksbury, D. (2007). Framing, agenda setting, and priming: The evolution of three media effects models. Journal of Communication, 57(1), 9-20.

Shah, D. V., Watts, M. D., Domke, D., \& Fan, D. P. (2002). News framing and cueing of issue regimes: Explaining Clinton's public approval in spite of scandal. The Public Opinion Quarterly, 66(3), 339-370.

TNS UK (2010). Public attitudes towards development. Spring 2010. TNS Report prepared for COI on behalf of the Department for International Development. London: TNS.

Valkenburg, P. M., Peter, J., \& Walther, J. B. (2015). Media effects: Theory and research. Annual Review of Psychology, 67, 315-338.

Van Gorp, B. (2007). The constructionist approach to framing: Bringing culture back in. Journal of Communication, 57(1), 60-78.

Van Gorp, B. (2010). Strategies to take subjectivity out of framing analysis. In P. D’Angelo \& J. A. Kuypers (Eds.), Doing news framing analysis: Empirical and theoretical perspectives (pp. 84-109). New York: Routledge.

Van Heerde, J., \& Hudson, D. (2009). 'The righteous considereth the cause of the poor'? Public attitudes towards poverty in developing countries. Political Studies, 58(3), 389-409.

Vossen, M., \& van Gorp, B. (2016). The battle of ideas about global poverty in the United Kingdom, the Netherlands, and Flanders. European Journal of Development Research.

YouGov (2012, September 10). What causes extreme poverty in developing countries? Retrieved March 29, 2016 from https://yougov.co.uk/news/2012/09/10/what-causes-extreme-poverty-developing-countries. 